\title{
Water quality and biological diversity of Budhoholi Wetland, Jhapa, East Nepal
}

\author{
Bhanu Kumar Bhattarai" and Diwas Dahal \\ Department of Zoology, Mechi Multiple Campus, T.U., Bhadrapur, Jhapa \\ *E-mail: bbhattarai69@gmail.com
}

\begin{abstract}
The present study deals with the physico-chemical parameters and biological diversity of Budhoholi at Sani-Arjun Municipality -7 Jhapa, from July to October, 2015. The physico-chemical properties of water were within the maximum permissible limit with slight variation in some parameters. The biological diversity was found to be rich. Riparian vegetation consisted of 21 herbs 13 shrubs, 11 trees and 4 climbers, 9 aquatic macrophytes and 21 species of fishes. The overall result of the lake indicated that the lake is not disturbed and is not polluted.
\end{abstract}

Kew words: Aquatic macrophytes, Fish diversity, Macrophytes, Physicochemical parameters, Riparian vegetation

\section{Introduction}

According to the 2003 National Wetlands Policy of Nepal, "Wetlands denote perennial water bodies that originate from underground sources of water or rain. It means swampy areas with flowing or stagnant fresh or salt water that are natural or man-made, or permanent or temporary. Wetlands also mean marshy lands, riverine floodplains, lakes, ponds, water storage areas and agricultural lands" (HMGN, 2003). Nepal's wetland habitat is created through varied water bodies that range from permanent flowing rivers to seasonal streams, lowland ox-bow lakes, high altitude glacial lakes, swamps, marshes, paddy fields, reservoirs and ponds (Bhandari, 1992). Lowlands of Nepal exhibit most extensive wetland systems which are playing important role in maintaining the ecology and economy of the regions but the people are not always aware of the economic value of the wetlands. Budho holi wetland is being set aside for park and recreational purpose, attracting large number of visitors which may alter the overall environmental condition of the entire lake ecosystem. Moreover wetlands of Nepal are in critical state and Budho Holi may not be far from it therefore regular monitoring of such virgin lake ecosystem is needed so as to conserve its biodiversity for its sustainable development.

\section{Materials and Methods \\ Study area}

A wetland, locally called Budhoholi is located about $6 \mathrm{~km}$ north from Birtamod Municipality, Jhapa. It is included in Sani-Arjun Municipality ward No. 7. It is under "Sukhani Shahid pratisthan Nepal" occupying an area of 22.4 ha. Previously this forested area was under the domain of "Namuna Samudaik Ban Samuha" having an area of 100 ha. Former HMG had provided this sector of forested land from a community forest group and declared to establish "Sahid Smarak Park". The wetland is surrounded by Bhimsen Ghat, lying on the way to Sanichare-Charali road on the north, Sarki Khola with a small Salbari 
village on the east and cultivated land on the west and south separated by Adua Khola respectively. Amidst it, a square park is located at a narrowing middle part of it. Regarding its origination, it is belived as an old course of Aduwa River.

The wetland is irregular in shape extended from northwest (inlet) to southeast (outlet). It is located from N 26 $40^{\prime} 37.4^{\prime \prime}$ to N $26^{\circ} 40^{\prime} 24.7^{\prime \prime}$ latitude and E $88^{\circ} 00^{\prime} 37.6^{\prime \prime}$ to E $88^{\circ} 00^{\prime} 53.3^{\prime \prime}$ longitude. Its diagonal length is $620 \mathrm{~m}$ and average breadth reaches to $98 \mathrm{~m}$, having an area of 3.45 ha $(\mathrm{Oli}, 2005)$. First part of the inlet is narrower whereas middle part broader and then the outlet slightly narrow down (Map 1). Depth of the wetland varies from outlet to inlet but at the center the average depth is $5 \mathrm{~m}$ (Rai \& Bhattarai, 2005). The wetland is covered with many shrubs and weeds, especially bryophytes and pteridophytes and surrounded by regenerated Sal forest.

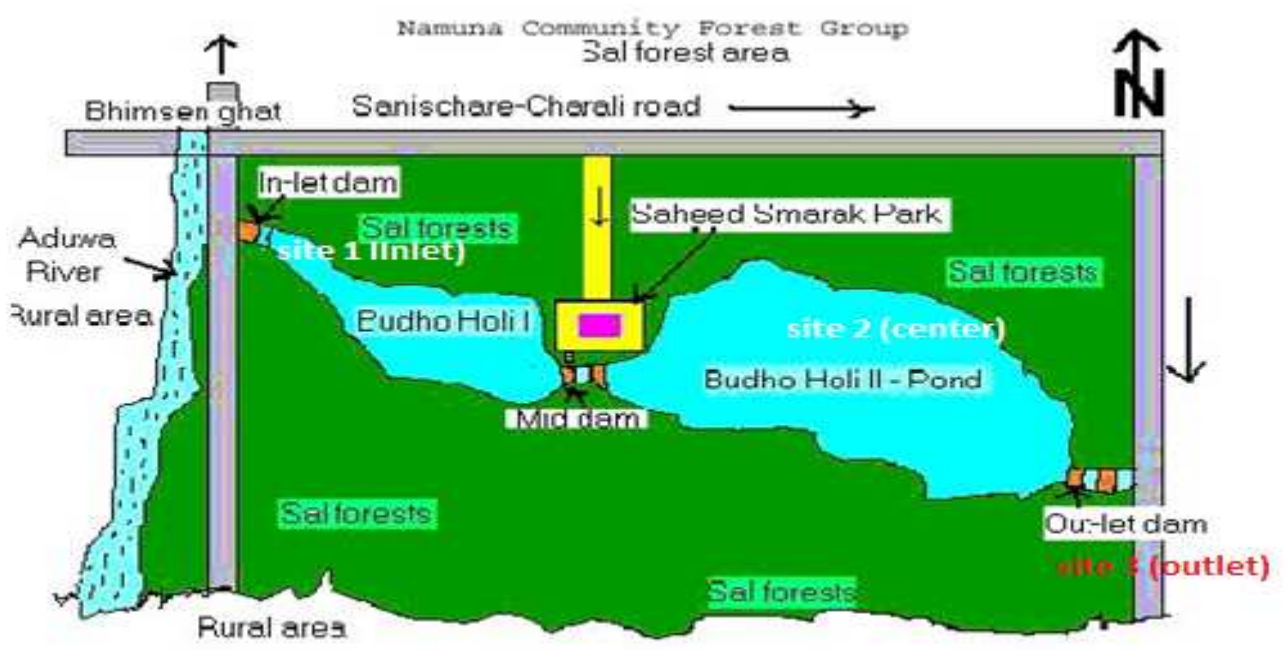

Figure 1. Diagrammatic Sketch of Bhudo Holi Wetland (Rai, 2003)

\section{Experimental design}

The study was carried out for three months from July to October 2015, in their respective first week. Depending upon the strata layout, three sampling site viz. inlet, center and outlet of the lake were selected to carry out the sampling of phyisco-chemical parameter of water. Aquatic macrophytes were also enumerated by fixing quadrat of $1 \mathrm{~m} \times 1 \mathrm{~m}$ from inlet and outlet. Both sampling of aquatic macrophytes and lake water were taken for three months of monsoon season (first week of July, August and September). The sampling of fish community and riparian vegetation were also carried out during same period. All the sampling was done between $9 \mathrm{AM}$ to $11 \mathrm{AM}$ in each sampling day.

\section{Site selection}

Based on the strata and feasibility of the Bhudo Holi Lake three sites were selected for the sampling purpose i.e.,

- Inlet : This site is at the inner mouth to the west ward of the lake at an elevation of about $135 \mathrm{~m}\left(26^{\circ} 40^{\prime} 607^{\prime \prime}\right.$ and $88^{\circ} 00^{\prime} 638^{\prime \prime}$ ') having water level of nearly $1 \mathrm{ft}$. It is fed by water from old course of the adjoining Adhuwa Khola. Two different samples were taken from the two corners of inlet portion for the sampling purpose. 
- Center: This is the main water body of the wetland ecosystem $\left(26^{\circ} 40^{\prime} 536^{\prime \prime}\right.$ and $88^{\circ} 00^{\prime} 759^{\prime \prime}$ ') where five samples were taken from the four corners and the central part of the water body for sampling purpose respectively. The depth variation was from $3 \mathrm{ft}$ to 9ft in this part of the wetland.

- Outlet: This site is below the dam which is boggy area (26 $40^{\prime} 516^{\prime \prime}$ and $\left.88^{\circ} 00^{\prime} 788^{\prime \prime}\right)$ with abundant vegetation. Two samples were taken from the outlet of two corners for the sampling purpose of research.

The physico-chemical parameters like temperature, $\mathrm{pH}$, transparency, $\mathrm{DO}$, free carbondioxide was measured immediately on the site at the time of sampling. Parameters like alkalinity, chloride, acidity, Nitrate, Phosphate TDS, TSS, TS and hardness were done in the laboratory of Mechi Multiple Campus and laboratory of SEAM-Nepal, Biratnagar in the same day within 4 to 6 hours as per the methods described in Trivedy and Goel (1984).

\section{Results and Discussion \\ Physico-chemical parameters}

The $\mathrm{pH}$ range (6.7-7.4) of the water samples were found within the range defined by WHO guidelines of 6.5-8.5 (WHO, 2004). It indicates good, favorable and suitable conditions for the optimal survival conditions for aquatic life. In the present study water transparency values ranged from 18 to $32 \mathrm{~cm}$ which indicates productive nature of this water on the basis of clarity values. Free carbon dioxide plays an ambient role in photosynthesis for chlorophyll bearing organism. High average value of free carbon dioxide i.e., $21.02 \mathrm{mg} / \mathrm{l}$ than that of WHO permissible level 10mg/l (WHO, 2004) was recorded in this study. High value of free carbon dioxide in the monsoon may be due to the diffusion of carbon dioxide from atmosphere with rain water and by the decomposition of organic matter. Alkalinity represents the buffering capacity of the water. The present value of our research showed an average of $17.7 \mathrm{mg} / \mathrm{l}$ of total alkalinity which is lower than that of WHO standard i.e. 200mg/l (WHO, 2004). The lower value indicates that the lake is not eutrophic, more over it may be due to high water level in monsoon (Table 1).

Table 1. Variation of different physico-chemical parameters.

\begin{tabular}{|c|c|c|c|c|c|c|c|c|c|c|c|}
\hline \multirow{3}{*}{$\mathbf{S N}$} & \multirow{3}{*}{ Parameters } & \multicolumn{9}{|c|}{ Months (2015) } & \multirow{3}{*}{ Mean } \\
\hline & & \multicolumn{3}{|c|}{ July } & \multicolumn{3}{|c|}{ August } & \multicolumn{3}{|c|}{ September } & \\
\hline & & Inlet & Center & outlet & Inlet & Center & outlet & Inlet & Center & outlet & \\
\hline 1 & Water temp. $\left({ }^{\circ} \mathrm{C}\right)$ & 28 & 30 & 30 & 29 & 30 & 30 & 30 & 30 & 30 & 30 \\
\hline 2 & $\mathrm{pH}$ & 6.7 & 7.2 & 6.8 & 6.9 & 7.4 & 7.4 & 6.8 & 7.3. & 7.4 & 7.1 \\
\hline 3 & Total alkalinity $(\mathrm{mg} / \mathrm{l})$ & 15 & 10 & 15 & 25 & 20 & 20 & 20 & 20 & 15 & 17.8 \\
\hline 4 & Total hardness (mg/l) & 24 & 22 & 24 & 22 & 20 & 22 & 24 & 20 & 20 & 21.8 \\
\hline 5 & Ca hardness(mg/l) & 8.8 & 7.2 & 7.2 & 5.6 & 4.8 & 4.0 & 5.6 & 4.8 & 4.0 & 5.7 \\
\hline 6 & Chloride (mg/l) & 11 & 3.5 & 3.6 & 10 & 3.5 & 3.5 & 11 & 3.8 & 3.6 & 5.9 \\
\hline 7 & Free $\mathrm{CO}_{2}(\mathrm{mg} / \mathrm{l})$ & 22 & 17.6 & 22 & 26.4 & 22 & 17.6 & 22 & 17.6 & 22 & 21.0 \\
\hline 8 & Tot. phosphorus (mg/l) & 0.07 & 0.1 & 0.07 & 0.07 & 0.1 & 0.07 & 0.08 & 0.1 & 0.07 & 0.08 \\
\hline 9 & Nitrate $(\mathrm{mg} / \mathrm{l}) \mathrm{v}$ & $<0.05$ & $<0.05$ & $<0.05$ & $<0.05$ & $<0.05$ & $<0.05$ & $<0.05$ & $<0.05$ & $<0.05$ & $<0.05$ \\
\hline 10 & Total acidity (mg/l) & 7.5 & 7.5 & 7.5 & 12.5 & 15 & 12.5 & 15 & 17.5 & 15 & 12.2 \\
\hline 11 & Transparency $(\mathrm{cm})$ & 27 & 20 & 30 & 21 & 18 & 32 & 20 & 18 & 30 & 24 \\
\hline 13 & Dissolved solid (mg/l) & 201 & 146 & 201 & 222 & 123 & 234 & 221 & 146 & 223 & 190.7 \\
\hline 14 & Total solid (mg/l) & 423 & 298 & 414 & 435 & 250 & 467 & 452 & 330 & 435 & 389.3 \\
\hline 15 & Dissolved $\mathrm{O}_{2}(\mathrm{mg} / \mathrm{l})$ & 6.0 & 5.6 & 5.6 & 6.0 & 6.0 & 5.6 & 6.0 & 5.6 & 5.2 & 5.8 \\
\hline
\end{tabular}


Total hardness is the sum of soluble $\mathrm{Ca}$ and $\mathrm{Mg}$ salts present in water. It also includes the sulphates and chlorides of calcium and magnesium. In the present investigation the average value of total hardness was found to be $21.7 \mathrm{mg} / \mathrm{l}$ which is well below the permissible limit of WHO i.e., $80-120 \mathrm{mg} / \mathrm{l}$ (WHO, 2004). High dilution of water during monsoon season and presence of lower amount of soluble salts might be the reason behind the lower concentration of total hardness present. Chloride ranged from 3.5 to $11 \mathrm{mg} / \mathrm{l}$ with a mean value of $6 \mathrm{mg} / \mathrm{l}$. The maximum value found in the inlet may be due to the contamination of sewage at the entrance point. Usually high concentration of chloride together with ammonia indicates sewage pollution. All the value of chloride was well below the permissible limit of WHO standards. This low value of chloride suggests, it is less likely that the water is contaminated with sewage in the wetland. Dissolved oxygen is an important aquatic parameter, whose presence is vital to aquatic fauna and flora. It plays crucial role in life processes of animals in water. In average $5.8 \mathrm{mg} / \mathrm{l}$ was the dissolved oxygen in the present result at different sites during different months. The lower value of dissolved oxygen may be due to higher rate of decomposition of organic matter during summer and rainy seasons. Total dissolved solids are simply the sum of cation and anion concentration expressed in $\mathrm{mg} / \mathrm{l}$. A high content of dissolved solid influence osmo regulation of fresh water organisms reduces solubility of gases like oxygen and result into eutrophication of the aquatic ecosystem. TDS in this lake fluctuated between 120 to $225 \mathrm{mg} / \mathrm{l}$ with average value of about $190 \mathrm{mg} / \mathrm{l}$ which suggest that the lake is not eutrophic. Phosphate has been considered as the main nutrient for the productivity of aquatic ecosystem. It occurs in both organic and inorganic form. It is the important nutrient essential to all the lentic community presents in an aquatic ecosystem (Lind, 1974).our findings revealed the lower value of the phosphate content. The lower value of phosphate might be due to rapid biological up take and the formation of water insoluble calcium carbonate. The result of nitrate was well below the permissible limit of WHO standard guidelines i.e. less than 0.05 . Generally nitrate comes directly from fertilizer application or from biological oxidation of ammonia (Acharya \& Rajbhandari, 2014). The low value of nitrate indicates that there is no risk for eutrophication of the lake. Low value of nitrate also supports less plankton growth. Low value may be due to the inactiveness of microbes or when decomposition rate becomes low or may also be due to the dilution of water bodies during monsoon season.

\section{Biodiversity}

The present study documented riparian vegetation with 4 species of climbers, 21 herbs, 13 shrubs, and 11 trees (Table 2).

Table 2. Plant species of Riperian vegetation in Bhudho holi wetland

\begin{tabular}{clllc}
\hline S.N. Scientific name & Nepali name & Family & Habit \\
\hline 1 & Schima wallichii (D.C.) Korth. & Chilaune & Theaceae & Tree \\
2 & Semicarpus anacordium L.f. & Bhayalo & Anacardiaceae & Tree \\
3 & Orozylum indicum (L.) Kurz & Tatelo & Bignoniaceae & Tree \\
4 & Woodfordia fruticosa (L.) Kurz & Botdhayero & Lythraceae & Tree \\
5 & Dillenia pentagyna Roxb. & Gineri & Dilleniaceae & Tree \\
6 & Sizygium cumini (L.) Skeels & Jamun & Myrtaceae & Tree \\
7 & Bauhinia purpurea L. & Takhi & Leguminosae & Tree \\
8 & Careya arborea Roxb. & Kumbi & Lecythidaceae & Tree \\
9 & Shorea robusta Gaertn. & Sal & Dipterocarpaceae & Tree \\
\hline
\end{tabular}




\begin{tabular}{|c|c|c|c|c|}
\hline 10 & Azadidachta indica A. Juss. & Neem patti & Meliaceae & Tree \\
\hline 11 & Alstonia scholaris (L.) R. Br. & Chattiwan & Apocynaceae & Tree \\
\hline 12 & Eupatorium adenophorum (Spreng) ${ }^{\mathrm{I}}$ & Banmara & Asteraceae & Shrub \\
\hline 13 & Antedesma diandrum $\mathrm{L}$. & Archale & Asclepiadaceae & Shrub \\
\hline 14 & Adhatoda vasica $\mathrm{L}$. & Asuro & Acanthaceae & Shrub \\
\hline 15 & Solanum surattense $\mathrm{L}$. & Bihi & Solanaceae & Shrub \\
\hline 16 & Datura metal L. & Dhatura & Solanaceae & Shrub \\
\hline 17 & Smilax macrophyla Blume & Kukurdaina & Smilaceae & Shrub \\
\hline 18 & Clerodendron viscosun Vent. & Bhatte & Verbenaceae & Shrub \\
\hline 19 & Calotropis gigantea (L.) Dryand. & Aank & Asclepiadaceae & Shrub \\
\hline 20 & Raodia spinosa $\mathrm{L}$. & Maidal & Rubiaceae & Shrub \\
\hline 21 & Colebrookea oppositifolia Sm. & Dhusre & Lamiaceae & Shrub \\
\hline 22 & Solanum torvum $\mathrm{Sw}$. & Bhemsenpatti & Solanaceae & Shrub \\
\hline 23 & Lyonia ovalifolia (Wall.) Drude & Angeri & Ericaceae & Shrub \\
\hline 24 & Lagerstromia speciosa (L.) Pers. & Asare & Lythraceae & Shrub \\
\hline 25 & Commelina bengalensis $\mathrm{L}$. & Kane jhar & Commelinaceae & Herb \\
\hline 26 & Ageratum conyzoides L. & Bantil & Asteraceae & Herb \\
\hline 27 & Acorus calamus L. & Bhojo & Araceae & Herb \\
\hline 28 & Phyllanthus parvifolius Buch.-Ham. ex D.Don & Khareto & Euphorbiaceae & Herb \\
\hline 29 & Lilium nepalensis D.Don & Ban lasun & Liliaceae & Herb \\
\hline 30 & Saccharum officinarum L. & Kash & Poaceae & Herb \\
\hline 31 & Mimosa pudica $\mathrm{L}$. & Lajawati & Leguminosae & Herb \\
\hline 32 & Tinosporia cordifolia (Lour.) Mers. & Burjo & Menispermaceae & Climbers \\
\hline 33 & Phyllanthus niruri L. & Bhui amala & Phyllanthaceae & Herb \\
\hline 34 & Dioscorea bulbifera L. & Bhayukar & Dioscoreaceae & Herb \\
\hline 35 & Centella asiatica (L.) Urban. & Ghod tappre & Apiaceae & Herb \\
\hline 36 & Rawolfia serpentine (L.) Benth. ex Kurz & Sarpagandha & Apocynaceae & Herb \\
\hline 37 & Murraya kaenigii (L.) Spreng. & Mitha neem & Rutaceae & Herb \\
\hline 38 & Lycopodium lucidulum Michx. & Nagbeli & Lycopodiaceae & Herb \\
\hline 39 & Crysopogan asiculatus L. & Kuro & Poaceae & Herb \\
\hline 40 & Leea aspera $\mathrm{L}$. & Galena & Leeaceae & Herb \\
\hline 41 & Eclipta prostrate L. & Bhumihraj & Asteraceae & Herb \\
\hline 42 & Oxalis corniculata $\mathrm{L}$. & Chariamilo & Oxalidaceae & Herb \\
\hline 43 & Ocimum gratissimum $\mathrm{L}$. & bantulashi & Lamiaceae & Herb \\
\hline 44 & Cynodon dactylon (L.) Pers. & Dhubo & Poaceae & Herb \\
\hline 45 & Imperata cylindrica (L.) P. Beauv. & Siru & Poaceae & Herb \\
\hline 46 & Bauhinia vahlii Wight \& Arn. & Bhorlo & Leguminosae & Climber \\
\hline 47 & Mikania micrantha Kunth $^{\mathrm{I}}$ & Banmaro laharo & Apocynaceae & Climber \\
\hline 48 & Spatholobus parviflorus (Roxb.)Kuntze & Debre laharo & Leguminosae & Climber \\
\hline 49 & Trachelosspermum lucidum (D.Don) K. Schu & Dudh laharo & Apocynaceae & Climber \\
\hline
\end{tabular}

Wetlands are the natural habitats which harbors a large number of endemic wildlife species both flora and fauna. Macrophytes contribute to maintain key functions and related biodiversity in fresh water ecosystem and to provide the needs of human society. Budhoholi wetland is rich in biodiversity with unique landscape. It has Sal dominated forest along the periphery and is characterized by the presence of some high altitude species like Chilaune, Lycopodium etc. and some invasive plant species like Banmara, Mikania etc. The tree 
species found here were all in the sapling stage except Sal. It can be concluded that after restoration of Bhudo Holi as park human activities were checked which favors the growth of other secondary species.

\section{Aquatic macrophytes}

Aquatic macrophytes were found less in number (Table 3). It was present only in the inlet and outlet of the wetland. Throughout the main water body i.e., the center, no aquatic macrophytes were found; it may be due to clearing of the wetland in regular interval and clearing of the dead trees from the shore line area by park management few months before our research period.

Table 3. List of macrophytes

\begin{tabular}{|c|c|c|c|}
\hline S.N. Scientific name & Local names & Family & Habit \\
\hline 50 Cyperus rotundus L. & Mothe & Cyperaceae & Emergent \\
\hline 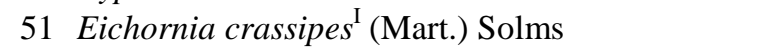 & Jalkumbhi & Pontederiaceae & Floating \\
\hline 52 Hydrilla verticelata (L.f.) Royle & Khasi & Hydrocharitaceae & Floating \\
\hline 53 Ludwigia hyssopifolia (G.Don) Exell & Khorsani jhar & Onagraceae & Emergent \\
\hline 54 Najas graminea Delile & - & Najadaceae & Submerged \\
\hline 55 Nelumbo nucifera Gaertn. & Kamal & Nymphaeaceae & Emergent \\
\hline 56 Polygonum barbatum L. & Pire jhar & Polygonaceae & Emergent \\
\hline 57 Potamogeton natans $\mathrm{L}$. & Nil-kamal & Potamogetonaceae & Submerged \\
\hline 58 Rotala rotundifolia (Buch-Ham ex Roxb) Koehne & - & Lythraceae & Emergent \\
\hline
\end{tabular}

${ }^{\text {I Invasive plant species }}$

\section{Fish diversity}

Fishes found in our study shows that there is decline in a number of species than reported in earlier literatures. Some larvivorous fishes dominate this wetland (Table 4). Local fishes were found only from the inlet and outlet sites but Aplochelius and Puntius species were present throughout the lake. It can be said that due to high water table of the lake and draining of the lake few months before as reported by the management committee the local species may have moved to downstream in the boggy area decreasing the number of species of fishes in the main water body of the wetland and also due to the heavy stocking of exotic species of carps for farming the local species may have been decreased and may lead to extinction in future if the trends continue.

Table 4. Wild and cultured fish species of Budho Holi wetland

\begin{tabular}{llll}
\hline Family & Zoological name & Nepali name & Remark \\
\hline Wild fishes & & & \\
Mastacembelidae & Macrognathus aculatus (Bloch) & Gaichi & Carnivorous \\
Channidae & Channa striatus (Bloch) & Saur & Larvivorous \\
Channidae & Channa gachua (Hamilton) & Hile & Larvivorous \\
Nandidae & Badis badis (Hamilton) & - & Larvivorous \\
Belontidae & Colisa fasciatus (Bloch \& Schneider) & Katare & Omnivorous \\
Cpprinodontidae & Aplocheilus panchax (Hamilton) & Tikuli & Larvivorous \\
Cyprinidae & Puntius chola (Hamilton) & Sidre & Larvivorous \\
Cyprinidae & Puntius sophore (Hamilton) & Pothi & Larvivorous \\
Cyprinidae & Puntius terio (Hamilton) & Ek thople pothi & Larvivorous \\
Cyprinidae & Denio rerio (Hamilton) & Zebra macha & Larvivorous \\
Cobitidae & Lepidocephalichthys guntea (Hamilton) & Painya & Larvivorous \\
\hline
\end{tabular}




\begin{tabular}{llll}
\hline Cobitidae & Noemacheilus botia (Hamilton) & Gadela & Carnivorous \\
Claridae & Clarius batrachus (Linneus) & Mungri & Carnivorous \\
Saccobranchidae & Heteropneustes fossilis (Bloch) & Singhi & Carnivorous \\
Bagaridae & Mystus cavasius (Hamilton) & Tengra & Planktonivorous \\
Belonidae & Xenontodon cancila (Hamilton) & Chuche bam & Carnijvorous \\
Anabantidae & Anabus testudineus (Bloch) & Kabai & Larvivorous \\
Amphipnoidea & Amphipnous cuchia (Hamilton) & Bam & Carnivorous \\
\hline Cultured fishes & & & \\
Cyprinidae & Labeo rohita(Hamilton) & Rohu & Detritivorous \\
Cyprinidae & Catla catla (Hamilton) & Bhakur & Planktonivorous \\
Cyprinidae & Cirrhinus mrigala (Hamilton) & Naini & Planktonivorous \\
Cyprinidae & Cyprinus carpio (Linneus) & Common carp & Omnivorous \\
Cyprinidae & Hypothalamichthys molitrix (Valencinneus) & Silver carp & Planktonivorous \\
Cyprinidae & Aristichthys nobilis (Richardson) & Big head & Planktonivorous \\
Cyprinidae & Ctenopharyngodon idella (Valencinneus) & Grass carp & Herbivorous \\
\hline
\end{tabular}

\section{Conclusions}

Bhudo holi wetland was studied for three months period which falls in the rainy season. The present study exhibits the status of the wetland to be ecologically balanced. The vegetation around the wetland is well conserved and it's dense. The overall productivity of the wetland is low. Hence all the fishes cultured were found to be under proper growth. The water was clear and less turbid. Almost all the results of physico-chemical parameters were within the standard permissible limits.

The physical aspect of the study showed the area to have warm humid climatic condition. The chemical parameters were found to be under permissible limits. Macrophytes diversity was found to be low due to low level of nutrients as the amount of phosphate and nitrate was low. Vegetation studied around $10 \mathrm{~m}$ periphery of the wetland was rich in composition comprising of 21 species of herbs most of which are of medicinal importance, 13 species of shrubs , 11 species of trees dominated by hard-wood, 4 species of climbers. Fish diversity reached to 21 species which includes some ornamental fishes like zebra fish and colisa. Most of the fish species were larvivorous in nature.

\section{Acknowledgements}

Authors are thankful to MOSTE, Singhdurbar and IOST, T.U. Kirtipur for providing financial and technical support to conduct this research work. We are indebted to Prof. Dr. D.R. Dangol for his immense support during pre and post report preparation period and Dr. B.R. Subba for helping in identifying fishes, to Mr. R. Uprety and Mr. K.P. Bhattarai for identifying plant specimens of the study area.

\section{References}

Acharya, P.M. \& S.L. Rajbhandari 2014. Habitats of Lutrogale perspicillate in the Narayani River, Chitwan National park, Nepal: Assessment of water quality. Journal of Indian Research 2: 67-76.

Bhandari, B. 1992. The current status of wetlands in Nepal. Country report presented at the Asian Wetlands Symposium organized by Ramsar Center, Japan (14-20 October), OtsuKushiru, Japan. 
HMGN 2003. National Wetlands Policy 2003, Kathmandu. His Majesty's Government of Nepal, Ministry of Forests and Soil Conservation (Approved on 6 March 2003 2059/11/22).

Lind, O.T. 1974. Handbook of common methods in limnology. C.V. Mosby Co., Saint Louis, USA. $199 \mathrm{p}$.

Oli, K.P. 2005. A draft on conservation and development plan for martyrs memorial area in Sanichare VDC. A report submitted to DDC, Jhapa, Nepal.

Rai, K.R. \& K.P. Bhattarai 2005. A study on restoration of Budho Holi wetland ecosystem for biodiversity conservation. A report submitted to DDC, Jhapa, Nepal.

Trivedy, R.K. \& P.K. Goel 1984. Chemical and biological method for water pollution studies $\left(1^{\text {st }}\right.$ ed.). Environmental Publication, Karad, India.

WHO 2004. Guidelines for drinking-water quality ( $3^{\text {rd }}$ ed.). WHO, Geneva, Switzerland. 